\title{
Fungal Proteolytic Enzymes
}

\section{Part I. Isolation of two Kinds of Acid-proteases Excreted by Aspergillus niger var. macrosporus*}

\author{
By Yoshihisa Koaze, Hitoshi Gor, Kazumi Ezawa, \\ Yujiro Yamada and Takeshi Hara \\ Research Laboratories, Meiji Seika Kaisha Ltd., Yokohama
}

\begin{abstract}
Two kinds of proteolytic enzyme, tentatively named acid protease $\mathrm{A}$ and $\mathrm{B}$ which showed a single peak on electrophoresis individually, were isolated from the crude enzyme powder obtained from the broth filtrate cultured with Aspergillus niger var. macrosporus. Acid protease B is similar too the fungal acid protease previously reported, because the enzyme exhibits optimum activity on milk casein at about $\mathrm{pH} 2.6$ and $55^{\circ} \mathrm{C}$ when the incubation was done at $\mathrm{pH} 2.6$. Acid protease $\mathrm{A}$ is a new proteolytic enzyme, because the enzyme exhibits optimum activity on milk casein at about 2.0 and $70^{\circ} \mathrm{C}$ or $60^{\circ} \mathrm{C}$ when the incubation was done at $\mathrm{pH} 2.6$ or 1.5 respectively.
\end{abstract}

\section{INTRODUCTION}

Microbial acid-proteases have been isolated from Aspergillus oryzae ${ }^{1)}$, Asp. saito $i^{2)}$, Paecilomyces variot ${ }^{3)}$, Trametes sanguinea ${ }^{4)}$ and so-called Butyl bacteria5) These enzymes digest milk casein well to produce a large amount of amino acid, and their optimal $\mathrm{pH}$ and optimal temperature for milk casein digestion lie in the region of $\mathrm{pH} 2.5 \sim 3.0$ and $55 \sim 60^{\circ} \mathrm{C}$.

In the course of studies on microbial enzymes in our laboratory, it has been observed that the broth filtrate cultured with the strain DBD-0406, which was newly isolated and identified with Aspergillus niger var.

\footnotetext{
* Prescrted af the Anrual Meeting of the Kanto Section of Agr. Chem. Soc. Japan held in Univ. of Jbaragi, Oct. 12, 1963.

1) K. Nakanishi, J. Biochem. Joban, 46, 1263 (1959).

2) J. Yoshida and M, Nagasawa, This Journal, 20, 257 (1956).

3) K. Tomoda and H. Shimazono, Proceeding of the lth Symposium on Enzyme Chem. Japan, 1962, p. 1.

4) T. Misaki et al., J. Agr. Chem. Soc. Japan, 35, 1264 (1961).

5) F. Uchino, K. Ito and S. Doi, ibid, 35, 719 (1961).
}

macrosporus by the authors ${ }^{6)}$, showed a strong proteolytic activity on milk casein in the $\mathrm{pH}$ range of $1.5 \sim 6.0$. The crude enzyme powder, prepared from the broth filtrate cultured with this strain, was purified by means of column chromatography using Sulfo Ethyl Cellulose after fractionation with ammonium sulfate. Two kinds of proteolytic enzymes, tentatively named acid protease $\mathrm{A}$ and $\mathrm{B}$, were isolated and each of these two enzymes showed single peak of them own on electrophoresis. Acid protease $B$ is similar to other fungal acid protease previously reported, because its optimal $\mathrm{pH}$ and optimal temperature incubated at $\mathrm{pH} 2.6$ for milk casein digestion lie about $\mathrm{pH} 2.6$ and $55^{\circ} \mathrm{C}$, and under the optimal condition this enzyme digests milk casein well to produce a large amount of amino acid.

On the other hand, acid protease $\mathrm{A}$ is a new proteolytic enzyme, because its optimal

6) Y. Koaze et $a l_{\text {, }}$, in press. 
$\mathrm{pH}$ and optimal temperature incubated at $\mathrm{pH} 2.6$ or 1.5 for milk casein digestion lie at about $\mathrm{pH} 2.0$ and $70^{\circ} \mathrm{C}$ or $60^{\circ} \mathrm{C}$, and the activity of this enzyme on amino acid formation from milk casein is less than that of acid protease B. Present paper deals with the isolation procedure of these two kinds of fungal acid proteases and effects of $\mathrm{pH}$ and temperature on their proteolytic activities on milk casein digestion.

\section{MATERIALS AND METHODS}

\section{The Crude Enzyme Powder.}

The crude enzyme powder used in this experiment was prepared from the broth filtrate cultured with Asp. niger var. macrosporus DBD-0406 as reported elsewhere ${ }^{(5)}$, and effects of $\mathrm{pH}$ and of the temperatures kept at $\mathrm{pH} 2.6$ or 1.5 on the activity on milk casein digestion were shown in Figs. 1 \& 2.

Preparation of Sephadex.

The two types of Sephadex, G-25 and G.75, which were products of the Pharmacia Co., were used. For purification of the crude enzyme powder, the Sephadex G.75 was equilibrated with $0.02 \mathrm{M}$ acetate buffer of $\mathrm{pH} 3.5$ containing $10^{-6} \mathrm{M}$ Ca acetate, and, for desalting of the partially purified enzyme, the Sephadex G-25 was equilibrated with Mcllvaine buffer $(\mu=0.03)$ of $\mathrm{pH} 2.6$ containing $10^{-3} \mathrm{M}$ Ca acetate.

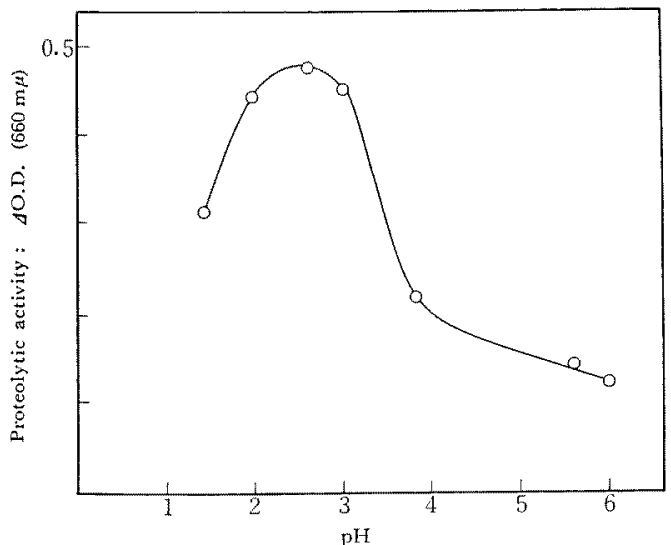

FIG. 1. The Effect of $\mathrm{pH}$ on Milk Casein Digestion by the Crude Enzyme Powder.

Five mal of $0.6 \%$ milk casein solution were digested with $1 \mathrm{ml}$ of the enzyme solution containing $0.167 \mathrm{mg}$ of the crude enzyme powder at $30^{\circ} \mathrm{C}$ for ten minutes at various $\mathrm{pH}$ from 1.5 to 6.0 . The proteolytic activity was assayed by the modited Anson's method.

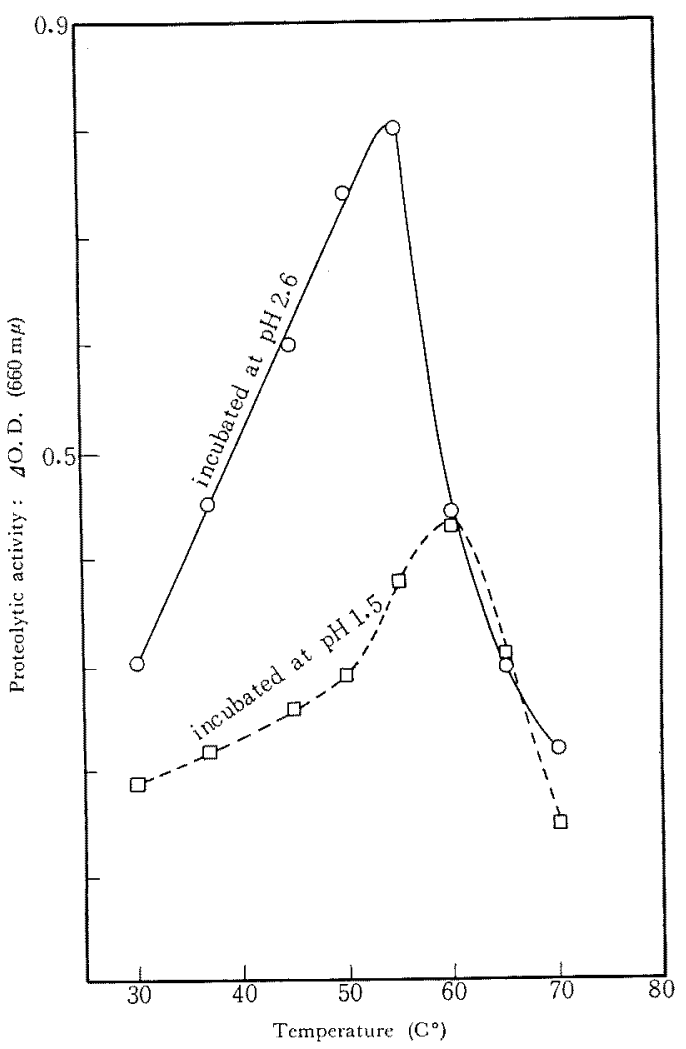

FIG. 2. The Effect of Temperature on Milk Casein Digestion by the Crude Enzyme Powder.

Five $\mathrm{ml}$ of $0.6 \%$ milk casein solution were digested with $1 \mathrm{ml}$ of the enzyme solution containing $0.07 \mathrm{mg}$ of the crude enzyme powder at $\mathrm{pH} 2.6$ for ten minutes at various temperatures from $30^{\circ} \mathrm{C}$ to $70^{\circ} \mathrm{C}$, and $0.15 \mathrm{mg}$ of the crude enzyme powder at $\mathrm{pH} 1.5$.

\section{Preparation of Sulfo Ethyl Cellulose.}

The Sulfo Ethyl Cellulose was a product of the Serva Co. And, for the isolation of acid protease A and $B$, this was equilibrated with the same buffer-salt solution as used for Sephadex G-25 as mentioned above.

\section{Protease Assay.}

Protcase activity was assayed by a modified Anson's method $^{\text {i) }}$ Usually reaction was carried out on milk casein (Casein according to Hammarsten, Merck) at $30^{\circ} \mathrm{C}$ for 10 minutes in $\mathrm{pH} 2.6$ or 1.5 . And when the effect of $\mathrm{pH}$ on proteolytic activity was investigated, $\mathrm{pH}$ was varied in the region of $1.0 \sim 5.6$. At

7) S. Akabori, "Method of Enzyme Research", Asakura Book Co. ltd., (2), 1956 , p. 240. 
$\mathrm{pH} 2.3$ or below, Walpole or Clark buffer was used and, at $\mathrm{pH} 2.6$ or above, Mcllvaine buffer was used. When the effect of temperature on proteolytic activity was investigated, temperature was varied in the region of $30 \sim 85^{\circ} \mathrm{C}$. The amount of non-proteinous product digested from milk casein during the incubation period was estimated either spectrophotometrically at $275 \mathrm{~m}_{\mu}$ or by use of the Folin reagent at $660 \mathrm{~m} \mu$.

\section{Quantitative Determination of Protein.}

Amount of protein in eluates obtained from the column chromatogram was determined by optical density at $280 \mathrm{~m}_{\mu}$ using Photo-Electro Spectrophotometer EPU 2A, Hitachi Ltd.

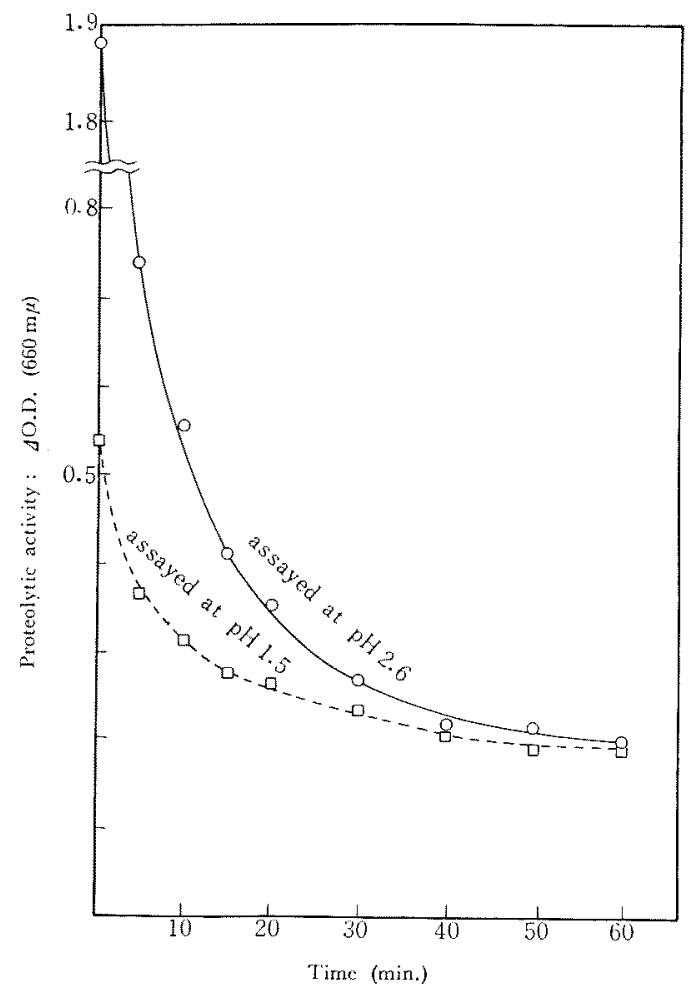

FIG. 3. Thermal Inactivation of the Proteolytic Activity of the Crude Enzyme Powder Kept at $\mathrm{pH} 2.6$.

$1.25 \mathrm{~g}$ of the crude encyme powder were dissolved in Walpole buffer of $\mathrm{pH} 2.6$ and filled up $10 \mathrm{ml}$ after adjusting to $\mathrm{pH} 2.6$. The enzyme solution was poured into $15 \mathrm{ml}$ of the same buffer as mentioned above pretheated at $55^{\circ} \mathrm{C}$ and kept at the same temperature successively. One $\mathrm{ml}$ aliquot of the enzyme solution kept as mentioned above was taken out at each time mentioned in the figure and their proteolytic activities for milk cascin digestion were assayed at $\mathrm{pH} 2.6$ and 1.5 .

\section{Electrophoresis.}

Specimens were dissolved in $0.02 \mathrm{M}$ phosphate buffer of pH 7.0 containing $0.1 \mathrm{M} \mathrm{NaCl}(\mu=0.18)$ and, using Tiselius type instrument HTB-2, Hitachi Ltd., the electrophoresis was done under condition of $6 \mathrm{~mA}$ and $3^{\circ} \mathrm{C}$.

\section{RESULTS AND DISCUSSION}

(1) Thermal Inactivation of the Crude Enzyme Pow. der.

When the crude enzyme powder was kept at $55^{\circ} \mathrm{C}, \mathrm{pH} 2.6$, proteolytic activities assayed at $\mathrm{pH} 2.6$ and 1.5 gradually decreased with the lapse of time. After fourty minutes, both proteolytic activities assayed at $\mathrm{pH} 2.6$ and 1.5 became almost the same (Fig. 3). On the other hand, when the crude enzyme powder was kept at $55^{\circ} \mathrm{C}, \mathrm{pH} 1.5$, proteolytic activities assayed at $\mathrm{pH} 2.6$ and 1.5 rapidly de-

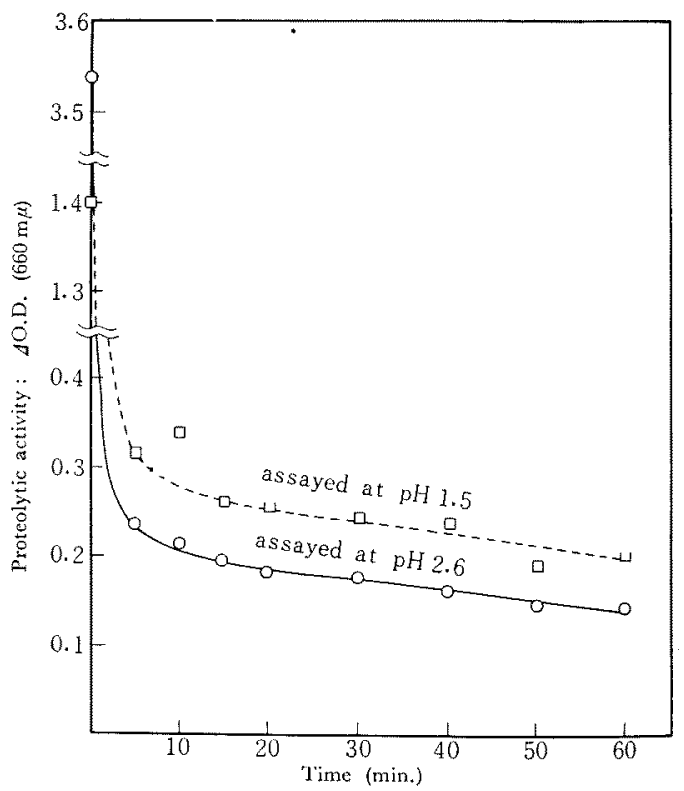

FIG. 4. Thermal Inactivation of the Proteolytic Activity of the Crude Enzyme Powder Kept at $\mathrm{pH} 1.5$.

$2.5 \mathrm{~g}$ of the crude enzyme powder were dissolved in Walpole buffer of pH 1.5. The enzyme solution was poured into $15 \mathrm{ml}$ of the same buffer as mentioned above pre-heated at $55^{\circ} \mathrm{C}$ and kept at the same temperature successively. One $\mathrm{ml}$ aliquot of the enzyme solution kept as mentioned above was taken out at each time mentioned in the figure and their proteolytic activities for milk cascin digestion were assayed at $\mathrm{pH} 2.6$ and 1.5 . 
creased. After five minutes, the proteolytic activity assayed at $\mathrm{pH} 1.5$ became higher than that assayed at $\mathrm{pH} 2.6$ (Fig. 4).

(2) Isolation of Acid Protease A and B.

All treatments were performed at $4^{\circ} \mathrm{C}$. As shown in Fig. 5, the crude enzyme powder was purified and subsequently the acid protease $\mathrm{A}$ and $\mathrm{B}$ were isolated as follows; (a) The crude enzyme powder was partially purified by means of column chromatography using Sephadex G-75. Then fractions having proteolytic activity, eluted from the Sephadex column with $0.02 \mathrm{M}$ acetate buffer of $\mathrm{pH} 3.5$ containing $10^{-3} \mathrm{M} \mathrm{Ca}$ acetate, were collected. (b) These fractions were added with ammonium sulfate to 0.5 saturation, then the precipitate was collected by centrifugation and freeze-dried (Enzyme Powder 1). (c) The supernatant was further added with ammonium sulfate to 0.75 saturation, then the precipitate was collected by centrifugation and freeze-dried (Enzyme Powder II). (d) The Enzyme Powder I and II were individually desalted and buffer-changed by means of col-

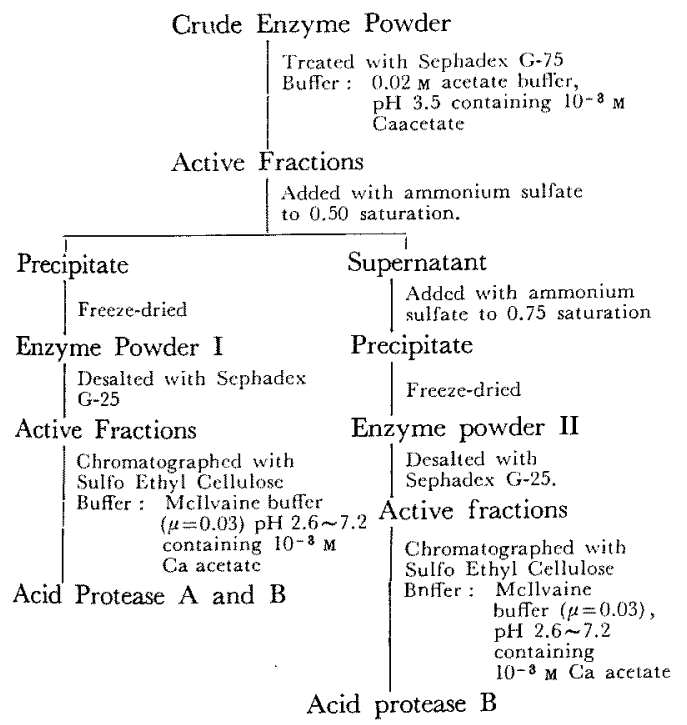

FIG. 5. The Isolation Procedure of Acid Protease A and $B$ from the Crude Enzyme Powder umn chromatography using Sephadex G-25, and fractions having proteolytic activity were applied to Sulfo Ethyl Cellulose column and eluted with McIlvaine buffer $(\mu=0.03)$ containing $10^{-3} \mathrm{M}$ Ca acetate with gradual change of $\mathrm{pH}$ from 2.6 to 7.2. As shown in Fig. 6, the distribution pattern of protein having five peaks was obtained from the column chromatography of Enzyme Powder I. Among them, protein fractions of the second and the fifth peak showed remarkable proteolytic activity. And protein fractions of the first and the third peak also showed weak proteolytic activity. On the other hand, as shown in Fig. 7, the distribution pattern of protein having the only one obvious peak which exhibits proteolytic activity was obtained from the column chromatography of Enzyme Powder II. These fractions exhibiting proteolytic activity were freeze-dried individually. Each proteolytic activity of protein fraction of the fifth peak obtained from the Enzyme Powder I (EP-Ie) and of the peak obtained from the Enzyme Powder II (EP-IIa) assayed at $\mathrm{pH}$ 2.6 was higher than that assayed at $\mathrm{pH} 1.5$. However, on the contrary, the proteolytic activity of the protein fraction of the second peak obtained from the Enzyme Powder I (EP-1b) assayed at $\mathrm{pH} 2.6$ was lower than that assayed at $\mathrm{pH}$ 1.5. Each proteolytic activity of protein fraction of the first and the third peak obtained from the Enzyme Powder I (EP-Ia \& -Ic) assayed at $\mathrm{pH} 2.6$ was also lower than that assayed at $\mathrm{pH} 1.5$.

(3) Effects of $\mathrm{pH}$ and Temperature on the Activity of Acid Protease A and B.

Effects of $\mathrm{pH}$ on proteolytic activities of the EP-Ie and of the EP-IIa were shown in Fig. 8. The optimal $\mathrm{pH}$ for milk casein digestion by the two preparations lies equally at aboui $\mathrm{pH} 2.6$, and their proteolytic activities assayed at $\mathrm{pH} 1.5$ were about $30 \%$ of that assayed at $\mathrm{pH} 2.6$, and proteolytic activities 


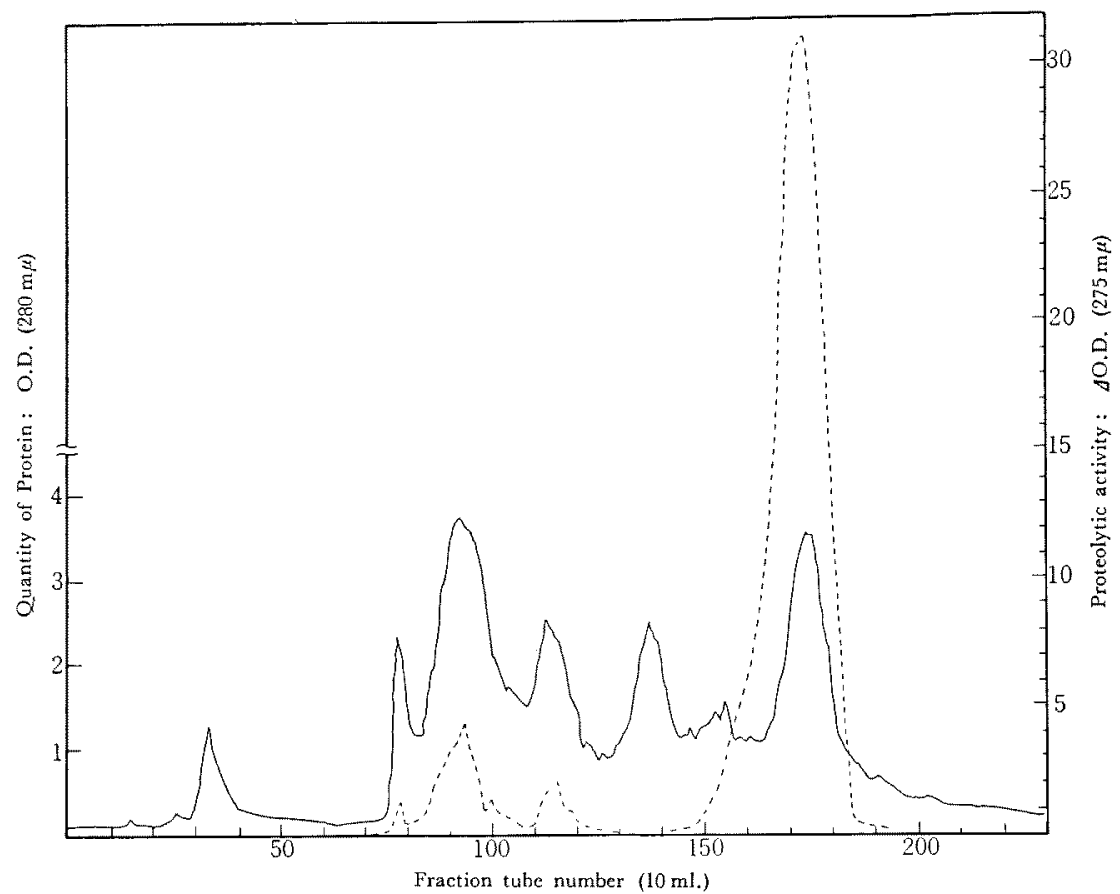

FIG. 6. Distribution of the Proteolytic Activity of the Enzyme Powder I on Sulfo Ethyl Cellulose Column Chromatogrm.

Five grams of the Enzyme Powder J were desalted by means of column chromatography using $100 \mathrm{~g}$ of Sephadex G-25. About $50 \mathrm{ml}$ of active fractions having proteolytic activity were applied to $30 \mathrm{~g}$ of Sulfo Ethyl Cellulose column equilibrated with Mcllvaine buffer $(\mu=0.03)$ of $\mathrm{pH} 2.6$ containing $10^{-8} \mathrm{M}$ Ca acetate. And then this was eluted with the same buffer-salt solution with gradual change of $\mathrm{pH}$ from 2.6 to 7.2 (these two $\mathrm{pH}$ solutions were both $1,000 \mathrm{ml}$ ), and each $10 \mathrm{ml}$ of eluate were collected in test tube. On each fraction, the quantity of protein was measured at $280 \mathrm{~m} / 2$ (solid line) and the proteolytic activity was assayed at $\mathrm{pH} 2.6$ (broken line).

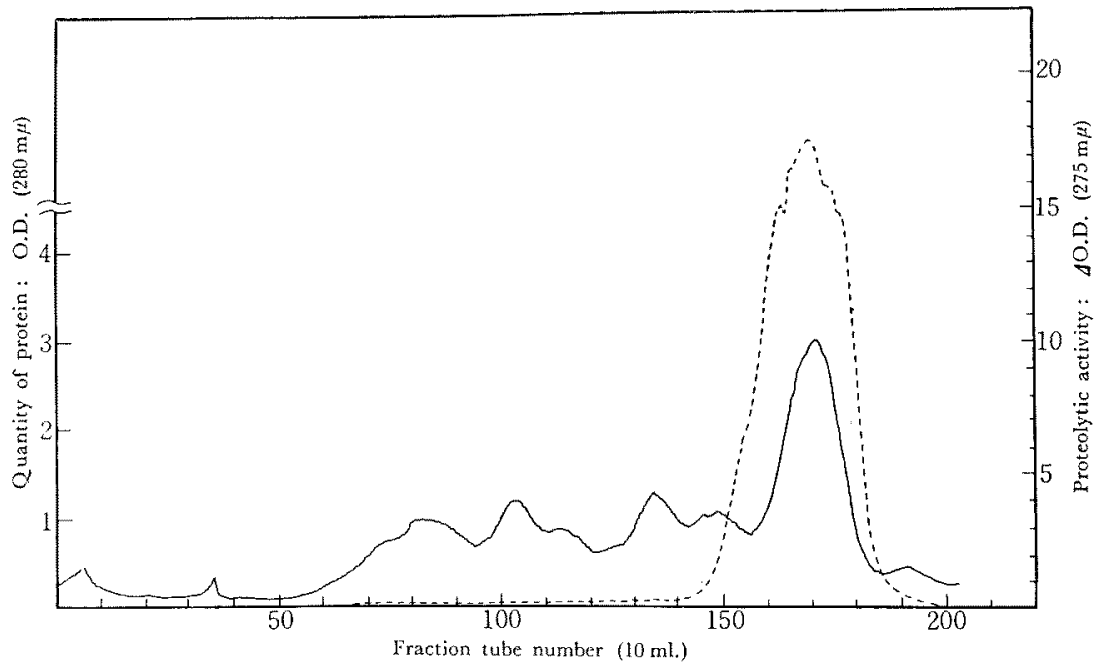

FIG. 7. Distribution of the Proteolytic Activity of the Enzyme Powder II on Sulfo Ethyl Cellulose Column Chromalogram.

Five grams of the Enzyme Powder II were desalted by means of column chromatngraphy using $100 \mathrm{~g}$ of Sephadex G.25. About $50 \mathrm{ml}$ of active fractions having proteolytic activity were applied to $40 \mathrm{~g}$ of Sulfo Ethyl Cellulose column equilibrated with the same buffer-salt solution as described in Fig. 6. Other conditions were the same as described in Fig. 6. 

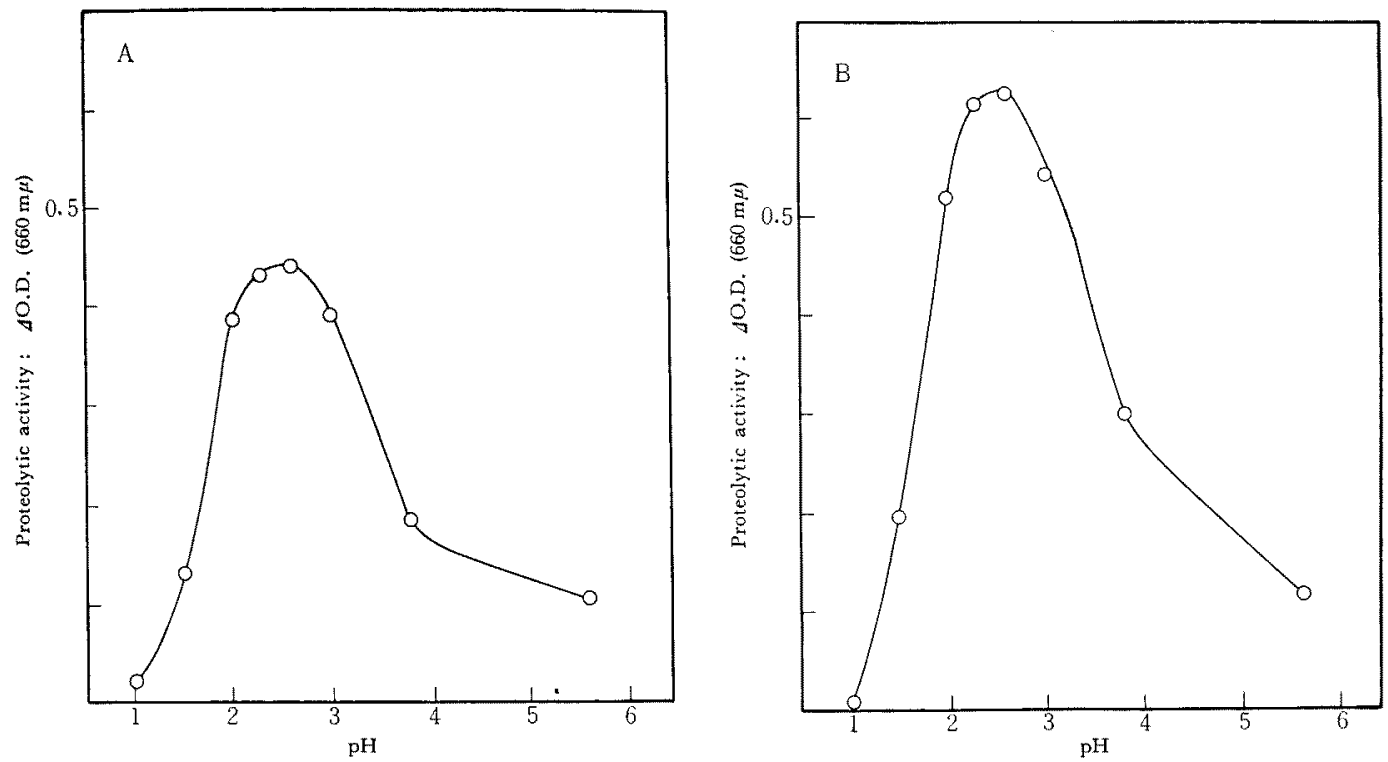

FIG. 8. Effects of $\mathrm{pH}$ on Milk Casein Digestion by Purified Preparations Tentatively Named Acid Protease B.

Five $\mathrm{ml}$ of $0.6 \%$ milk cascin solution were digested with $1 \mathrm{ml}$ of the enzyme solution containing $0.0285 \mathrm{mg}$ of EP-le (left) and $0.0448 \mathrm{mg}$ of EP-Ila (right) at $30^{\circ} \mathrm{C}$ for ten minutes at various $\mathrm{pH}$ values from 1.0 to 5.6 .
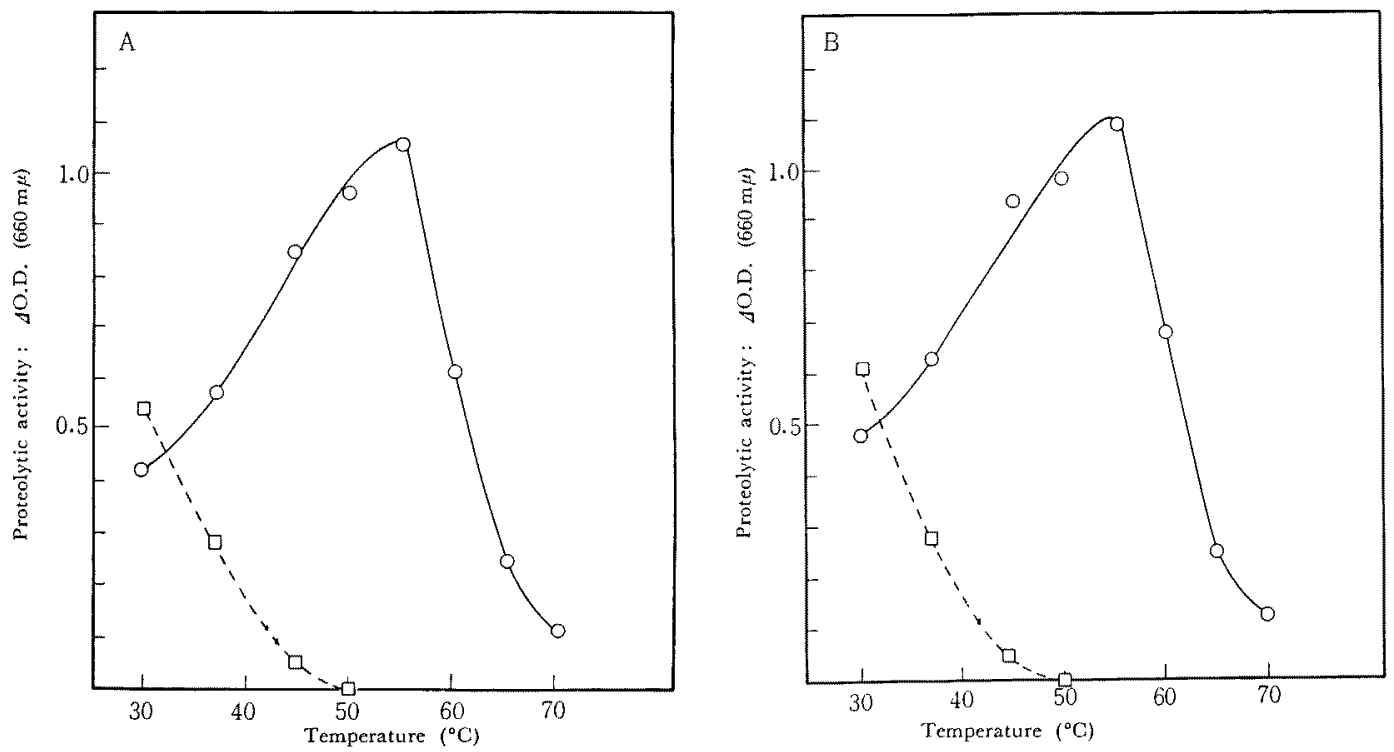

FIG. 9. Effects of Temperature on Milk Casein Digestion by Purified Preparations Tentatively Named Acid Protease B.

Five ml of $0.6 \%$ milk casein solution were digested at $\mathrm{pH} 2.6(-\mathrm{O}-$ ) with $1 \mathrm{ml}$ of the enzyme solution containing $0.0288 \mathrm{mg}$ of EP-Ie (left) or $0.0283 \mathrm{mg}$ of EP-IIa (right) for ten minutes at various temperatures from $30^{\circ} \mathrm{G}$ to $70^{\circ} \mathrm{C}$. And also the digestion of mik casein was carried out at $\mathrm{pH} 1.5(--\square--)$ with $0.288 \mathrm{mg}$ of EP-Je (left) or $0.283 \mathrm{mg}$ of EP-1la (right), 
assayed at $\mathrm{pH} 1.0$ were almost undetectable. Furthermore, effects of temperature on pro-

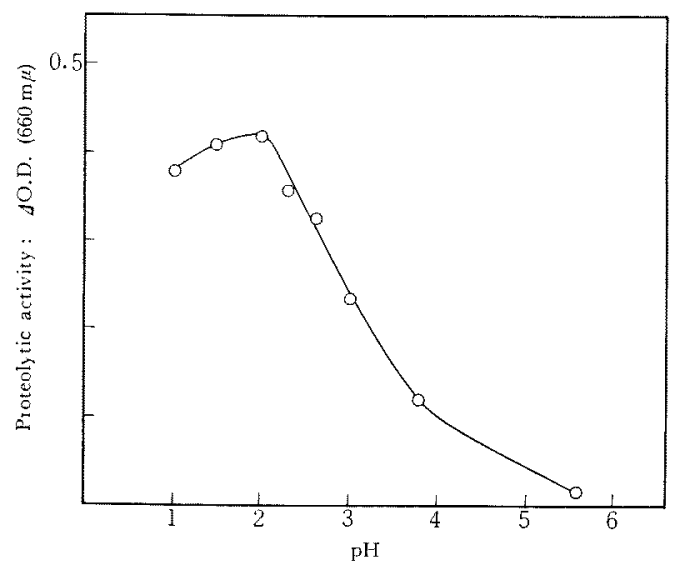

FIG. 10. The Effect of $\mathrm{pH}$ on Milk Casein Digestion by the Purified Preparation Tentatively Named Acid Protease A.

Five ml of $0.6 \%$ milk casein solution were digested with $1 \mathrm{ml}$ of the cnzyme solution containing $0.51 \mathrm{mg}$ of EP-1b at $30^{\circ} \mathrm{C}$ for ten minutes at various $\mathrm{pH}$ values from 1.0 to 5.6 .

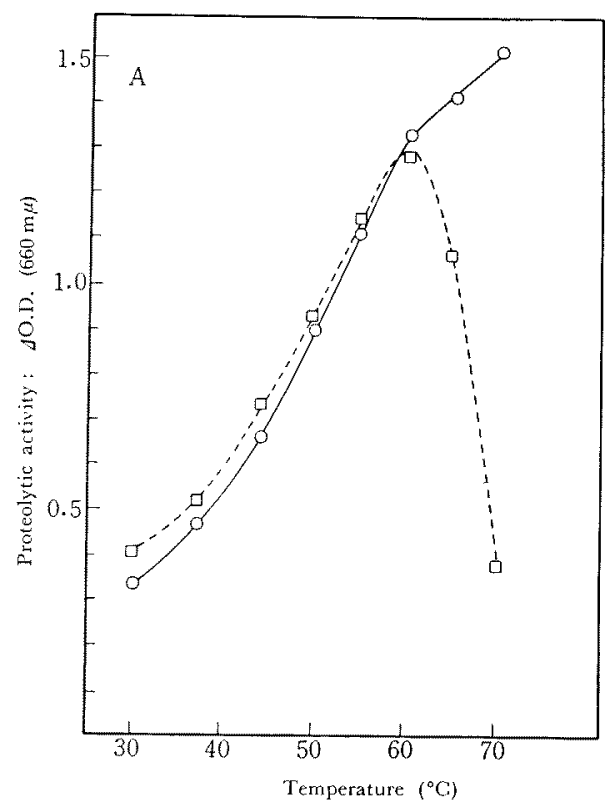

teolytic activities of the two preparations were shown in Fig. 9. The optimal temperature incubated at $\mathrm{pH} 2.6$ for milk casein digestion by both preparations lies equally at about $55^{\circ} \mathrm{C}$ and that incubated at $\mathrm{pH} 1.5$ decreased almost linearly with the rise of temperature above $30^{\circ} \mathrm{C}$. Therefore these two preparations were obviously identical with each other and the enzyme was tentatively named acid protease $\mathbf{B}$ and this type of enzyme is considered to be similar to well-known fungal acid protease previously reported by many investigators $^{1-4)}$ On the other hand, the effect of $\mathrm{pH}$ on the proteolytic activity of the EP-Ib was shown in Fig. 10. The optimal pH for milk casein digestion by this preparation lies at about $\mathrm{pH} 2.0$, and its proteolytic activities assayed at $\mathrm{pH} 1.5$ and 1.0 were about $125 \%$ and $115 \%$ of that assayed at $\mathrm{pH} 2.6$ respectively. Furthermore the effect of tem-

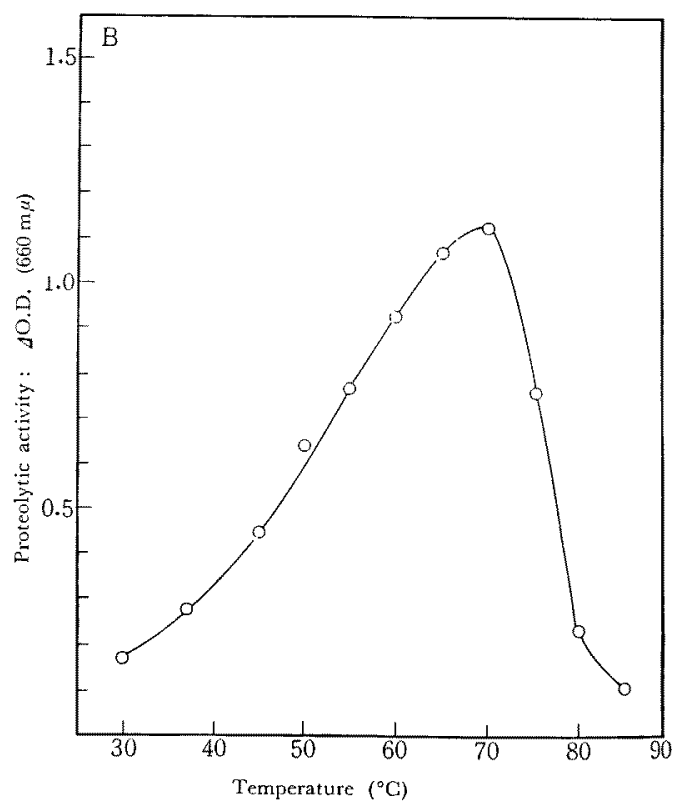

FIG. 11. The Effect of Temperature on Milk Casein Digestion by Purified Preparation Tentatively Named Acid Protease A.

Five $\mathrm{ml}$ of $0.6 \%$ milk casein solution were digested at $\mathrm{pH} 2.6(-\mathrm{O}-)$ with $1 \mathrm{ml}$ of the enzyme solution containing $0.51 \mathrm{mg}$ (Acft) or $0.284 \mathrm{mg}$ (right) of El'- Ib for ten minutes at various temperatures from $30^{\circ} \mathrm{C}$ to $85^{\circ} \mathrm{C}$. And also the digestion of nilk casein was carried out at pHI $1.5(--\square--)$ with $0.51 \mathrm{mg}$ of the same enzyme. 

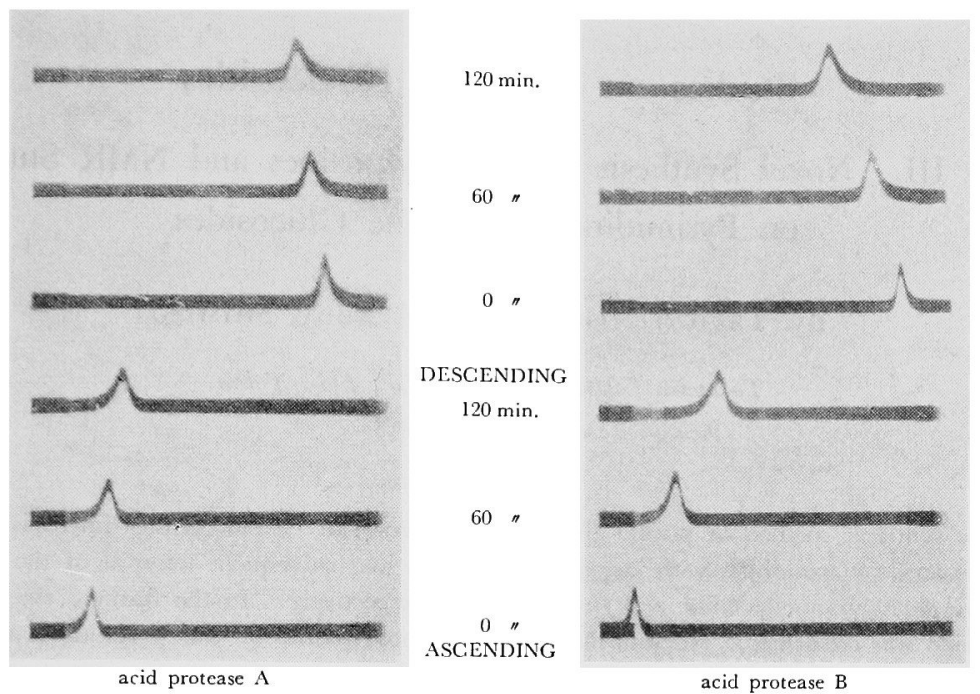

FIG. 12. Photographs of Electrophoresis of Acid Protease A and B Using the Tiselius type instrument.

The acid protease A (EP-lb, left) or the acid protease B (EP-le, right) was individually dissolved in $0.02 \mathrm{M}$ phosphate buffer pH 7.0 containing $0.1 \mathrm{M} \mathrm{NaCl}(\mu=0.18)$. Using the Tiselius type instrument HTB-2, Hitachi Ltt., the electrophoresis on these enzymes was individually carried out under conditions of $6 \mathrm{~mA}$ and $3^{\circ} \mathrm{C}$.

perature on the proteolytic activity of this preparation was shown in Fig. 11. The optimal temperature incubated at $\mathrm{pH} 2.6$ for milk casein digestion by this preparation lies at about $70^{\circ} \mathrm{C}$ and that incubated at $\mathrm{pH} 1.5$ lies at about $60^{\circ} \mathrm{C}$. Therefore this preparation is believed to be a new proteolytic enzyme not yet reported and tentatively named acid protease $\mathrm{A}$.

As shown in Fig. 12, both acid protease A and $B$ gave a single peak on the electro- phoresis using the Tiselius type instrument. Acknowledgements. The authors wish to express their sincere thanks to Prof. K. Arima, Univ. of Tokyo, for his kind suggestion on this report.

The authors wish to thank Mr. M. Inomata and Miss K. Katsumata for technical assistance and also members of Pharmaceutical Development of Kawasaki Plant for preparation of the crude enzyme powder. 